\title{
Kandungan Total Lipid Lemak Ayam dan Babi Berdasarkan Perbedaan Jenis Metode Ekstraksi Lemak
}

\author{
The Total Lipid Content of Chicken and Pork Fats \\ Based on Different Extraction Methods \\ Aminullah'1a, Mardiah', Muhammad Reza Riandi' ${ }^{1}$, Arum Puspito Argani' ${ }^{1}$, Gustini \\ Syahbirin², Tetty Kemala²
}

${ }^{1}$ Jurusan Teknologi Pangan dan Gizi, Fakultas Ilmu Pangan Halal, Universitas Djuanda Bogor; Jl. Tol Ciawi No. 1, Ciawi, Bogor 16720

2Departemen Kimia, Fakultas Matematika dan Ilmu Pengetahuan Alam, Institut Pertanian Bogor ;jl. Raya Darmaga, Kampus IPB Darmaga, Bogor 16680

aKorespondensi: Aminullah, E-mail: aminullah@unida.ac.id

(Diterima oleh Dewan Redaksi : 5 - 03 - 2018)

(Dipublikasikan oleh Dewan Redaksi : 14 - 04 - 2018)

\begin{abstract}
Chicken and pork fats were by-product of the chicken and pork processing industry that were usually used for certain purposes. The fat extraction method determines the total lipid of fat. The objective of the research was to study the effect of different fat extraction methods on the total lipid of chicken and pork fats. Four extraction methods, namely Soxhlet, Folch, Hara and Radin, and Bligh and Dyer methods were used in this research and the materials were chicken and pig fats. The results showed that the total lipids which were produced by Soxhlet, Folch, Haran and Radin, and Bligh and Dyer in chicken fat were 54.28\%, 70.06\%, $63.87 \%$, and $44.21 \%$, respectively. While in pig fat were $65.57 \%, 86.97 \%, 67.74 \%$, and $64.07 \%$, respectively. The use of different extraction methods will provide different efficiency on amounts of lipids. The difference in results was due to the characteristics of different fatty acid constituents between chicken and pork fats.
\end{abstract}

Keywords: Chicken fat, pork fat, extraction method, total lipid

\begin{abstract}
ABSTRAK
Lemak ayam dan babi merupakan produk samping dari industri pengolahan daging ayam dan babi yang biasanya digunakan untuk keperluan tertentu. Metode ekstraksi lemak menentukan hasil dari total lipid dari lemak. Tujuan dari penelitian ini adalah untuk mempelajari pengaruh dari perbedaaan metode ekstraksi lemak terhadap hasil total lipid dari lemak ayam dan babi. Penelitian ini menggunakan empat metode ekstraksi, yaitu metode Soxhlet, Folch, Hara and Radin, dan Bligh and Dyer serta bahan yang digunakan adalah lemak ayam dan babi. Hasil penelitian menunjukkan bahwa total lipid yang dihasilkan dari metode ekstraksi Soxhlet, Folch, Haran and Radin, dan Bligh and Dyer pada lemak ayam, berturut-turut adalah 54,28\%, 70,06\%,63,87\%, dan 44,21\%. Sedangkan pada lemak babi, berturut-turut, adalah 65,57\%, 86,97\%, 67,74\%, dan 64,07\%. Penggunaan metode ektraksi yang berbeda akan memberikan efisiensi pada jumlah lipid yang berbeda. Perbedaan hasil tersebut juga disebabkan oleh karakteristik asam lemak penyusun yang berbeda antara lemak ayam dan lemak babi.
\end{abstract}

Kata kunci: lemak ayam, lemak babi, metode ekstraksi, total lipid

Aminullah, Mardiah, Muhammad Reza Riandi, Arum Puspito Argani, Gustini Syahbirin, dan Tetty Kemala. 2018. Pengaruh Jenis Metode Ekstraksi Lemak terhadap Total Lipid Lemak Ayam dan Babi. Jurnal Agroindustri Halal 4 (1): $094-100$. 


\section{PENDAHULUAN}

Lemak hewani merupakan lemak yang sering dimanfaatkan dalam pengolahan pangan sebagai hasil samping contohnya adalah lemak ayam dan babi. Lemak ayam adalah lemak yang didapat (biasanya sebagai produk sampingan) dari rendering dan pengolahan ayam. Lemak ayam memiliki asam linoleat yang tinggi, asam lemak omega-6. Tingkat asam linoleat antara $17,9 \%$ dan $22,8 \%$. Lemak ayam dapat diperoleh dari bagian ampela ayam karkas, terutama ayam karkas dengan berat hidup lebih dari 2 kilogram. Kandungan lemak yang menempel pada bagian ampela ayam karkas tersebut, berbanding lurus mengikuti bobot karkas ayam hidupnya. Semakin berat tubuh ayam karkas tersebut, semakin banyak pula lemaknya. Kandungan lemak ayam karkas banyak ditemukan pada tiga bagian tubuh ayam, yaitu dada, boneless paha, dan tunggir (Andreas, 2016). Menurut Triyantini et al. (1997) daging ayam bagian paha memiliki kandungan lemak yang lebih tinggi dibandingkan dengan bagian dada.

Lemak babi yang diambil dari bagian dinding perut merupakan yang paling tinggi kualitasnya. Bagian tersebut mempunyai tekstur yang lembut, berwarna putih dan memiliki nilai asam yang tidak lebih dari 0,8. Lemak babi dari organ lain dan bagian belakang mempunyai nilai asam maksimal 1,0. Lemak babi diperoleh dengan cara $d r y$ rendering. Dry rendering merupakan suatu cara yang digunakan untuk mengektraksi lemak hewan dengan cara pemanasan tanpa air (Winarno, 1997). Lemak babi memiliki kandungan trigliserol yang lebih sedikit daripada trigliserol pada lemak sapi. Oleh sebab itu, lemak babi melebur pada temperatur yang lebih rendah (Belitz \& Grosch, 1987). Lemak babi merupakan salah satu ingridient yang sangat penting dalam proses pengolahan pangan baik sebagai media penggorengan atau sebagai bahan campuran dalam pembuatan margarin, shortening, dan produk lemak lainnya.

Metode ekstraksi yang umum digunakan dalam mengekstrak lemak yaitu metode Soxhlet, metode Folch, metode Hara and
Radin, dan metode Bligh and Dyer. Metode ekstraksi Soxhlet merupakan metode analisis kadar lemak secara langsung dengan cara mengekstrak lemak/minyak dari bahan pangan dengan pelarut organik non-polar, seperti heksana, petroleum eter dan dietil eter dengan menggunakan alat khusus yaitu ekstraktor soxhlet. Walaupun dalam perkembangannya metode ini tidak hanya terbatas untuk ekstraksi lemak/minyak. Metode Folch merupakan salah satu metode yang paling umum digunakan oleh ahli lemak atau lipidologis di seluruh dunia. Metode ini menggunakan campuran pelarut dari kloroform/methanol dan etanol/dietil eter (Young et al. 2001). Metode Bligh and Dyer dikembangkan sebagai metode yang ekonomis untuk mengekstrak lipid dari sejumlah besar jaringan basah, khususnya jaringan ikan beku, dengan mengggunakan volume pelarut yang minimum (Christie, 2011b). Keunggulan utama dari metode ini adalah pengurangan rasio sampel dengan pelarut, dari 1 bagian sampel dalam 20 bagian pelarut pada metode klasik Folch menjadi 1 bagian sampel berbanding 3 bagian campuran pelarut kloroform/methanol diikuti 1 atau 2 bagian kloroform. Walaupun dengan pengurangan pelarut, metode ini dapat menghasilkan rendemen sekitar 95\% dari lemak total (Iverson et al. 2001). Hara dan Radin (1978), mengembangkan metode ekstrasi dengan campuran pelarut heksana dan isopropanol yang toksisitasnya relatif rendah dan limbahnya tidak terlalu berbahaya. Prinsipnya adalah Ekstraksi menggunakan ekstraksi pelarut 1-langkah (1-step) dengan pelarut heksana:isopropanol (3:2 v/v) yang diikuti dengan pencucian oleh larutan sodium sulfat.

Menurut Habeck et al. (2013) dan Macedo et al. (2012), perbedaan metode ekstraksi akan memberikan data jumlah dan jenis lemak yang berbeda, maka dari itu pemilihan metode ekstraksi lemak ayam dan lemak babi perlu dilakukan untuk melihat sejauh mana metode ekstraksi yang digunakan dapat menghasilkan data total lipid. Tujuan dari penelitian ini adalah untuk mempelajari pengaruh dari perbedaaan 
metode ekstraksi lemak terhadap hasil total lipid dari lemak ayam dan babi.

\section{MATERI DAN METODE}

\section{Bahan}

Penelitian diawali dengan perajangan atau pengirisan lemak ayam dan babi yang diperoleh dari Pasar Bogor di Kota Bogor yang kemudian di ekstrak dengan menggunakan empat metode ekstraksi pelarut yang umum digunakan, yaitu metode Soxhlet, Folch, Hara and Radin, dan Bligh and Dyer. Diagram alir penelitian ini dapat dilihat pada Gambar 1. Selain itu, bahan lainnya yang digunakan adalah kloroform, metanol, aquades, isopronanol, $\mathrm{Na}_{2} \mathrm{SO}_{4}$, minyak nabati, garam $\mathrm{NaCl}$, sodium sulfat, air destilata (aquades) dan bahan kimia penunjang lain.

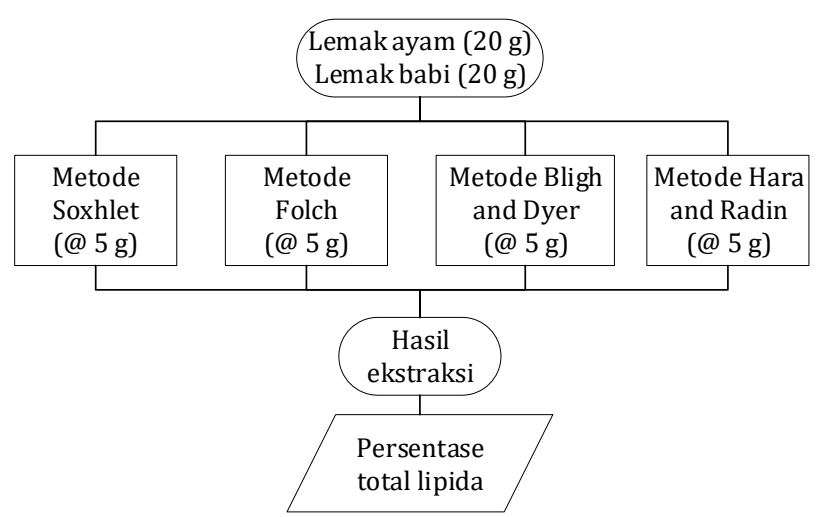

Gambar 1. Diagram alir proses ekstraksi lemak ayam dan babi

\section{Ekstraksi Pelarut}

\section{Metode Soxhlet (AOAC, 1995)}

Labu lemak dikeringkan dengan oven bersuhu $105^{\circ} \mathrm{C}$ selama sekitar 15 menit. Sampel ditimbang sebanyak $5 \mathrm{~g}$ kemudian dimasukkan ke dalam selongsong lemak. Kertas saring berisi sampel tersebut diletakkan dalam alat ekstraksi soxhlet yang dirangkai dengan kondensor. Pelarut heksana dimasukkan ke dalam labu lemak lalu sampel direfluks selama 5 jam. Sisa pelarut dalam labu lemak dihilangkan dengan dipanaskan dalam oven, lalu ditimbang (AOAC, 1995).

$$
\text { Kadar lemak }(\%)=\frac{\text { berat lemak }}{\text { berat sampel }} \times 100 \% \text { (1) }
$$

\section{Metode Folch (Folch et al., 1957)}

Sampel sebanyak $5 \mathrm{~g}$ ditambahkan pelarut klorofom:metanol (2:1) sampai volume akhir 100mL. Campuran dihomogenkan selama 15-20 menit menggunakan magnetic stirrer dengan kecepatan 300 rpm pada suhu ruang. Kemudian, campuran tersebut disaring dengan corong Buchner dengan bantuan penyaring vakum. Selanjutnya, hasil penyaringan ditambahkan dengan larutan $\mathrm{NaCl}$ 0,88 \% sebanyak 20mL. Kemudian dihomogenkan kembali selama 1 menit dan ditunggu untuk pemisahan 2 fase. Lapisan atas dipisahkan, lapisan bawah atau fase klorofom yang mengandung lipid dievaporasi (Folch et al., 1957).

\section{Metode Bligh and Dyer (Bligh and Dyer, 1959)}

Sampel sebanyak $5 \mathrm{~g}$ ditambahkan pelarut kloroform:metanol (1:2) sebanyak $15 \mathrm{~mL}$. Campuran dihomogenkan dengan orbital shaker selama 60 menit pada suhu ruang. Campuran kemudian dihomogenkan kembali dengan $5 \mathrm{~mL}$ kloroform. Selanjutnya campuran tersebut disaring dengan corong Buchner dengan bantuan penyaring vakum. Kemudian hasil penyaringan tersebut ditambahkan $5 \mathrm{~mL} \quad \mathrm{NaCl} \quad 0,88 \%$ dan dihomogenkan kembali selama 1 menit. Selanjutnya didiamkan untuk pemisahan dua fase. Lapisan atas dipisahkan, lapisan bawah atau fase klorofom yang mengandung lipid dievaporasi (Bligh and Dyer, 1959).

\section{Metode Hara and Radin (Hara and Radin, 1978)}

Sejumlah 5 gram sampel ditambahkan 90 $\mathrm{mL}$ pelarut heksan:isopropanol (3:2) disingkat HIP. Campuran dihomogenisasi 1520 menit menggunakan magnetic stirrer dengan kecepatan 300 rpm pada suhu ruang. Suspensi yang terbentuk disaring dengan corong Buchner dengan bantuan penyaring vakum. Saat penyaringan residu, corong 
dibasuh dengan $2 \mathrm{~mL}$ HIP sebanyak 5 kali, biarkan pelarut merendam selama 2 menit sebelum diberi tekanan vakum. Untuk memisahkan komponen non-lipid, filtrate ditambahkan $60 \mathrm{~mL} \mathrm{Na}_{2} \mathrm{SO}_{4}$ dan divortex selama 2 menit. Lipid yang terdapat pada lapisan atas atau lapisan yang kaya akan heksana kemudian dievaporasi (Hara and Radin, 1978).

\section{Analisis statistik}

Hasil analisa lemak diolah dalam bentuk ANOVA (analisis sidik ragam). Apabila berbeda nyata maka dilanjutkan dengan uji Duncan. Program pengolah data yang digunakan adalah SPSS ${ }^{\circledR}$.

\section{HASIL DAN PEMBAHASAN}

Jaringan adiposa atau jaringan lemak secara umum mengandung 76-94\% lipid, 14\% protein, dan 5-20\% air (Alm, 2013). Hasil dari ekstraksi lemak ayam dan babi mentah dengan metode ekstraksi Folch, Soxhlet, Hara and Radin, dan Bligh and Dyer dapat dilihat pada Gambar 2.
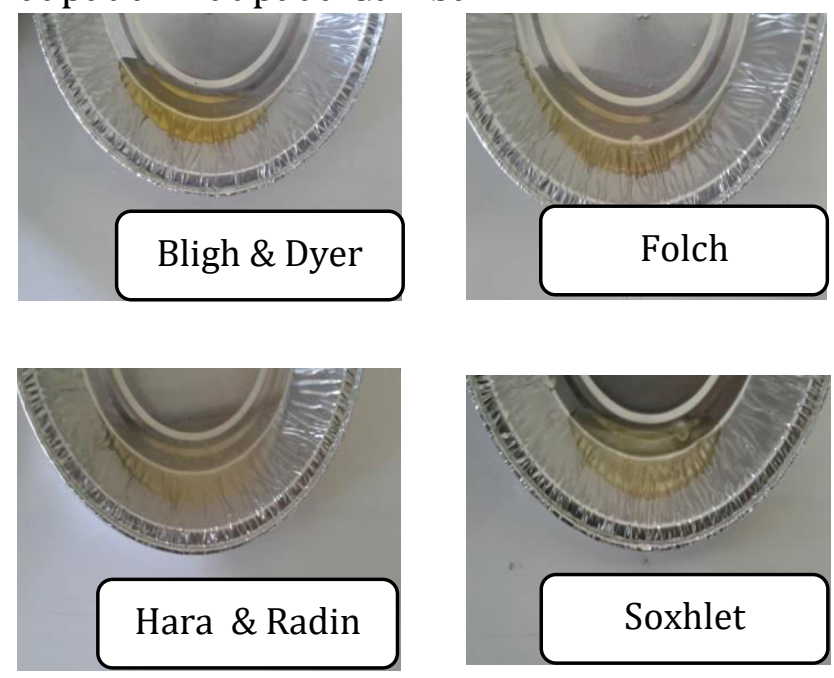

Gambar 2. Hasil ekstrak lemak dengan berbagai metode ekstraksi

Lemak ayam dan babi yang diekstrak dilakukan pemotongan dengan cara diiris dan penimbangan. Pengirisan ini bertujuan untuk mempermudah ekstraksi pada lemak. Lemak yang telah ditimbang diekstraksi dengan menggunakan metode Soxhlet, Folch,
Hara \& Radin dan Bligh \& Dyer untuk mendapatkan total lipid. Dari keempat metode ekstraksi lemak ayam dan babi yang telah dilakukan diperoleh bobot total lipida yang berbeda seperti terlihat pada Tabel 1 .

Tabel 1. Bobot total lipida lemak ayam

\begin{tabular}{lllll}
\hline $\begin{array}{l}\text { Jenis } \\
\text { Lemak }\end{array}$ & $\begin{array}{l}\text { Metode } \\
\text { Ekstraksi }\end{array}$ & $\begin{array}{l}\text { Berat } \\
\text { Awal } \\
\text { (g) }\end{array}$ & $\begin{array}{l}\text { Berat } \\
\text { Akhir } \\
\text { (g) }\end{array}$ & $\begin{array}{l}\text { Total } \\
\text { Lipid } \\
(\%)\end{array}$ \\
\hline \multirow{2}{*}{ Lemak } & FO & 5,03 & 2,73 & $54,28^{\mathrm{b}}$ \\
Ayam & B\&D & 5,30 & 3,72 & $70,06^{\mathrm{c}}$ \\
& H\&R & 5,20 & 3,32 & $64,21^{\mathrm{a}}$ \\
\hline
\end{tabular}

Huruf superscript yang berbeda pada satu kolom per lemak yang digunakan menunjukkan perbedaan yang nyata $(\mathrm{p}<0.05)$

Tabel 2. Bobot total lipida lemak babi

\begin{tabular}{lllll}
\hline Jenis & Metode & $\begin{array}{l}\text { Berat } \\
\text { Awal }\end{array}$ & $\begin{array}{l}\text { Berat } \\
\text { Akhir } \\
\text { (g) }\end{array}$ & $\begin{array}{l}\text { Total } \\
\text { Lipid } \\
(\%)\end{array}$ \\
\hline \multirow{2}{*}{ Lemak } & SO & 5,55 & 4,83 & $86,97^{\mathrm{a}}$ \\
Babi & B\&D & 5,09 & 3,34 & $65,57^{\mathrm{b}}$ \\
& H\&R & 5,26 & 3,31 & $64,07 \mathrm{~b}$ \\
\end{tabular}

Huruf superscript yang berbeda pada satu kolom per lemak yang digunakan menunjukkan perbedaan yang nyata $(\mathrm{p}<0.05)$

Berdasarkan hasil analisis ragam yang diperoleh dapat diketahui bahwa terdapat perbedaan nyata $(\mathrm{P}<0,05)$ total lipid lemak ayam pada keempat metode ekstraksi. Pada Tabel 1 dapat diketahui bahwa metode Folch dapat mengekstrak lipid lebih tinggi yaitu 70,06\% dibandingkan dengan Hara and Radin. Perbedaan total lipid ini diduga disebabkan oleh tidak efisiennya metode Hara and Radin untuk ekstraksi Gangliosida (Hara dan Radin, 1978). Aminullah et al. (2018a) melaporkan bahwa penggunaan metode ekstraksi Folch merupakan metode ekstraksi lemak yang terpilih berdasakan uji statistik pada asam lemak penyusunnya dan 
uji Priciple Component Analysis. Begitupun Soxhlet dengan bobot total lipid 54,28\%, jauh lebih rendah dibandingkan dengan metode Folch. Ekstraksi Soxhlet dipengaruhi oleh banyak faktor, seperti ukuran partikel bahan, pemilihan pelarut, waktu ekstraksi dan suhu ekstraksi (Mamidipally, 2004 dan Li et al., 2014). Hal ini sesuai dengan studi Pérez-Palacios et al (2008) menyatakan bahwa hasil bobot total lipid metode Soxhlet lebih rendah daripada metode Folch. Total lipid terendah ditunjukkan oleh metode Bligh and Dyer $(44,21 \%)$. Hal ini sejalan dengan hasil penelitian Iverson et al (2001) yang menunjukkan untuk sampel yang mengandung lipid lebih dari $2 \%$, metode B\&D menghasilkan kadar lipid yang lebih rendah secara signifikan dari metode Folch (Fo) dan perbedaan tersebut semakin meningkat dengan bertambahnya kadar lipid. Hal ini dapat disebabkan sedikitnya jumlah pelarut yang digunakan sehingga pelarut lebih mudah jenuh. Metode ini biasa digunakan untuk mengekstraksi lipida total dari berbagai bahan makanan. Namun awalnya dikembangkan untuk sampel ikan dengan kandungan lipid di bawah 1\%, kandungan air sekitar 80\% dan kadar fosfolipid tinggi. Walaupun Bligh and Dyer (1959) menyatakan bahwa metode tersebut dapat diterapkan pada jaringan biologis lainnya, disarankan agar sampel dengan kandungan lemak tinggi memerlukan modifikasi metode. Selain itu, penelitian Aminullah et al. (2018b) menunjukkan bahwa metode ekstraksi Bligh and Dyer juga menghasilkan total lipid yang paling rendah pada lemak sapi mentah dengan persentase $55,16 \%$.

Tabel 2 menunjukkan bahwa ekstraksi lemak babi dengan menggunakan metode Folch, Soxhlet, Hara and Radin, dan Bligh and Dyer memiliki persentase total lipid, berturut-turut, sebesar $65,57 \%, 86,97 \%$, $67,74 \%$, dan 64,07\%. Hasil ini menunjukkan penggunaan metode ektraksi yang berbeda akan memberikan efisiensi pada jumlah lipid yang berbeda pula (Ramalhosa et al., 2012). Hasil total lipid menunjukkan metode Soxhlet memberikan hasil persentase tertinggi dibandingkan tiga metode lainnya.
Ukuran sampel tentunya mempengaruhi hasil ekstraksi, semakin luas permukaan partikel maka interaksi dengan partikel akan semakin besar. Selain itu penggunaan pelarut juga berpengaruh, hal ini karena penggunaan pelarut yang berbeda serta tingkat kepolaran pelarut juga berbeda. Pelarut Soxhlet bersifat non polar sehingga lebih mudah dalam mengekstraksi lemak yang bersifat non polar. Hal ini sesuai dengan penelitian yang telah dilakukan oleh Aminullah et al. (2018b) yang menunjukkan bahwa metode ekstraksi Soxhlet menghasilkan total lipida yang paling tinggi dibandingkan metode lainnya pada lemak sapi mentah.

Perbedaan hasil total lipid antara lemak ayam dan babi yang terlihat pada Tabel 1 dan 2 dapat disebabkan oleh konstituen asam lemak yang menyusun lemak tersebut. Li et al. (2014) menjelaskan bahwa profil dan rendemen lipid sangat tergantung dari kondisi sumber lemak, disrupsi sel, polaritas pelarut, dan proses ekstraksi. Akan tetapi, Perez-Palacios et al. (2008) menjelaskan juga bahwa metode Folch dan Soxhlet merupakan metode yang paling efektif dan relatif sama dalam menentukan kadar lipid dari produk daging. Pernyataan ini diperkuat dari data penelitian yang menunjukkan bahwa metode ekstraksi Soxhlet dan Folch memberikan hasil yang paling tinggi dalam persentase total lipida pada lemak ayam dan babi serta pada lemak sapi mentah yang telah diteliti oleh Aminullah et al. (2018b).

\section{KESIMPULAN}

Hasil penelitian menunjukkan bahwa total lipid yang dihasilkan dari metode ekstraksi Soxhlet, Folch, Haran and Radin, dan Bligh and Dyer pada lemak ayam, berturut-turut adalah 54,28\%, 70,06\%, $63,87 \%$, dan 44,21 \%. Sedangkan pada lemak babi, berturut-turut, adalah $65,57 \%$, 86,97 \%, 67,74 \%, dan 64,07 \%. Penggunaan metode ektraksi yang berbeda akan memberikan efisiensi pada jumlah lipid yang berbeda. Perbedaan hasil tersebut juga disebabkan oleh karakteristik asam lemak 
penyusun yang berbeda antara lemak ayam dan lemak babi.

\section{UCAPAN TERIMA KASIH}

Penelitian ini didukung Hibah Penelitian Kerjasama Antar Perguruan Tinggi (PKPT) dengan nomor kontrak 1598/K4/KM/2017 dari Kementerian Riset, Teknologi, dan Pendidikan Tinggi, Republik Indonesia.

\section{DAFTAR PUSTAKA}

Alm M. 2013. Animal Fats. http://lipidlibrary.aocs.org/OilsFats/cont ent.cfm?ItemNumber $=40320$ (7 Februari pukul 16.25).

Aminullah, Mardiah, Hakim L, Argani AP, Syahbirin G. 2018a. Effect of fat extraction methods to the fatty acid and infrared profiles of chicken fat using GCMS and FTIR, Asian Journal of Chemistry. 30: 1317-1320.

Aminullah, Mardiah, Sutsuga $\mathrm{H}$, Kemala T. 2018b. Study of different extraction methods on finger print and fatty acid of raw beef fat using fourier transform infrared and gas chromatography-mass spectrometry. Open Chemistry. In Press

Andreas W. 2016. Lemak Ayam. https://andreaswardjogo.wordpress.com L2016/02/08/lemak-ayam/amp/ (16 Juli 2017 pukul 20.00).

Association of Official Analytical Chemist [AOAC]. 1995. Official Method of Analysis of Association of Official Analytical Chemist. Ed ke-14. AOAC inc.

Belitz HD and Grosch W. 1987. Food Chemistry. Springer Verlag. Canada.

Bligh EG, and Dyer WJ. 1959. A rapid method of total lipid extraction and purification. Can. J. Biochem. Physiol., 37: 911-917.

Christie WW. 2011b. Extraction of Lipids from Tissues - A Beginner's Guide. http://lipidlibrary.aocs.org/History/cont ent.cfm?ItemNumber $=40362$. Diunduh pada tanggal 7 Februari pukul 16.35.

Folch J, Lees M, Sloane SGH. 1957. A simple method for the isolation and purification of total lipids from animal tissues. J. Biol. Chem. 226:497-509.

Habeck S, Mitchell B, Sullivan D. 2013. Comparison of Fat Extraction Methods for Analysis of Meat. Covance Laboratories Inc, Madison, Winconsin. Chicago. Illinois.

Hara A, and Radin NS. 1978. Lipid extraction of tissues with a low-toxicity solvent. J.Anal. Biochem. 90:420-426.

Iverson SJ, Lang SLC, Cooper MH. 2001. Comparison of the bligh and dyer and folch methods for total lipid determination in a broad range of marine tissue. Lipids. 36,1283-1287.

Li Y, Naghdi FG, Garg S, Adarme VTC, Thurecht KJ, Abdul Ghafor W, Tannock S, Schenk PM. 2014. A comparative study: the impact of different lipid extraction methods on current microalgal lipid research. Microbial Cell Factories. 13:14.

Macedo REF, Pflanze SB, Gomes CL.2012. Probiotic Meat Products (17 Februari 2017 pukul 14.50).

Mamidipally PK, Liu SX. 2004. First approach on rice brand oil extraction using limonene. European Journal of Lipid Science And Technology. 106: 122-125.

Pérez-Palacios T, Ruiz J, Martín D, Muriel E, Antequera T. 2008. Comparison of different methods for total lipid quantification in meat and meat products. J. Food chemistry. 110: 1025-1029.

Ramalhosa MJ, Paiga P, Morais S, Alves MR, Matos CD, Oliveira MBPP. 2012. Lipid content of frozen fish:comparison of different extraction methods and variability during freezing storage. Food Chemistry. 131: 328-336.

Triyantini, Abubakar, Bintang IAK, Antawidjaja T. 1997. Studi Komperatif Preferensi, Mutu Dan Gizi Beberapa Jenis Daging Unggas. Jurnal. Ilmu Ternak Dan Veteriner. Vol.2. No.3. Puslitbang Peternakan. Bogor.

Winarno FG. 1997. Kimia Pangan dan Gizi. Gramedia Pustaka Utama. Jakarta. 
Young 0, Frost D, West J, Braggins T. 2001. Analytical methods In Meat Science Applications. Y. H. Hui (Ed.). New York: Marcel Dekker Inc. 